\title{
Troubled Homecomings: Rosa Praed and Lemuria ${ }^{1}$
}

\author{
Kay Ferres
}

\section{Landscapes and histories}

This paper has many beginnings. My interest in Rosa Praed's involvements with spiritualism and theosophy has taken me into the nineteenth century literatures and practices of spiritualism, to debates about the specification of human nature and human origins and to the recent literature on the administration and regulation of populations in the cities at the centre of Empire and the colonial periphery. But my thinking about Lemuria had been caught up with the 'nowhere' of Utopian discourse.

Michael Sharkey (1983), John Docker (1991) and Robert Dixon (1993, 1995) have all located Rosa Praed's Fugitive Anne: A Romance of the Unexplored Bush (1902) in the tradition of Lemurian legend. This has consequences for the way space is represented in their readings: the novel is located in both an intertextual space and an imaginary landscape as a lost city romance. But what struck me most on first reading it were the continuities with earlier Praed work which engaged with the politics of marriage reform, specifically with the debates occasioned by the Married Women's Property Acts (1870 and 1882), the Matrimonial Causes Act (1878) and the Infant Custody Acts (1873 and 1886). My inclination was to locate its interests, then, in a specific set of power relations in a historical time and place, and to see Anne's rejoicing in her 'freedom' not as an expression of yearning but as a political claim.

In August 1991, the weekend Australian Magazine published an article on the tabling of a report commissioned by the Northem Territory government, The Gulf Region Land Use and Development Study - 1991. My attention was drawn by the magazine's cover, depicting a landform labelled 'The Lost City', and by the report's description of two 'scenic areas' to be opened for tourism and managed by the Northern Territory Conservation Commission: the 'Lost City' of Nathan River and the 'Paradise Pools' at the McArthur River, both significant ceremonial sites for Aboriginal groups of the Gulf. What interested me was not just the apparent resembiances with the landscape of Fugitive Anne but the reporter, Dennis Schulz's, account of sighting this place: 
For an hour, you glide above the rocky, featureless sea of desert. Nothing much moves below you in these far reaches of the Gulf country, only the odd string of feral donkeys and a few scrawny brumbies spooked by the roar of the chopper, and the occasional wallaroo.But then, out of this fractured landscape, something deviates on the horizon. As you approach from the air, it seems to shake itself free from the savannah, then leap abruptly. Suddenly, you make out thousands of rounded spires, sculpted like smooth towers, cutting for kilometres across a wide valley....

You feel as if you are the first to have seen this (Schulz 1991: 8).

Schulz's report reiterates the tropes of lost city romances: at the same time as it notes the significance of these sites to local Aboriginal groups, it erases the signs of human habitation from the landscape. This city has been locked away 'behind the cast iron gates of pastoralism', and missed by most (European) explorers. The Aboriginal people whose traces remain there were long since removed to Borroloola, which when gazetted had a population of ' 30 whites, 24 Chinese, 20 transients' and by 1889 , a library of 3000 volumes (Schulz 1991: 12).

This record of the remnants of a colonial past had some resonances for me with the cataclysmic end of the lost civilisation in Praed's narrative, and the few objects its survivors - Anne Marley, Kombo and Eric Hansen - preserve. What to do with them? Hansen, a natural historian, embarks on lecture tours, accompanied by Anne. Kombo is an adjunct to this display of scientific knowledge: he and Anne in different ways legitimate scientific 'regimes of truth'. The 1991 Northern Territory report recommended strategies for land management in an area bordering the Gulf of Carpentaria. Its author, Graeme Hockey, translated those recommendations for the Australian's reporter: 'tourism is the go, coupled with pastoralism and mining' (Schulz 1991: 9). The Northern Territory pastoralists turn tour guides: this country is rediscovered and remapped, but ecological tourism still follows European contours and relies on European technology. There's scant mention of Aboriginal interest in this enterprise in The Australian's report, filed before the 1993 Mabo decision. But nor is there much interest in the curious trace of early European occupation: the library with its 3000 volumes.

The comparison of this Lost City with the lost civilisation of the Red People also reawakened in me an ongoing unease with work on space in social theory and cultural studies. As Jane Jacobs notes in surveying the proliferation of spatial metaphors in recent colonial discourse analysis and postcolonial theory, 'real' geographies are in practice difficult to locate in this work; though material and imagined geographies are theorised as mutually constitutive, the material disappears: 'the spatial is metaphorically everywhere but oft-times nowhere' (Jacobs 1996: 3). By contrast with the Nathan River 'city', the space of Praed's 'unexplored bush' is not empty. Rather, it is like Henri Lefebvre's 'abstract space': 'For Lefebvre, space becomes abstract only as a result of the crushing of lived experience and its vanquishing by concepts and representations' (Rose 1999: 32). Praed's narrative exposes this process of 'crushing' and 'vanquishing' and, to the extent that it 
reproduces the conventions of 'romance', itself participates in the process.

The 'real' geographies of late-nineteenth century London and the permeable boundaries where the northern Australian coast faces Asia represent the extremities of Praed's narrative. At the end of a voyage from Britain, Anne and Kombo disappear from a ship which has just navigated the Torres Strait, and is heading southward. Anne disguises herself as a 'Lascar' boy: cross-dressing gives her mobility in this multi-racial contact zone. Kombo conducts her through a series of colonial encounters in the region of Cape York and the Gulf of Carpentaria, before his place is taken by the naturalist, Hansen. I want to suggest that colonial encounters occur in this novel at both the permeable frontier of the Gulf of Carpentaria and the centre of Empire.

Both the London of the late nineteenth century, and the Gulf of Carpentaria (in the nineteenth century, but also for a considerable time before European contact) are multi-racial spaces. Though Eurocentric histories of occupation begin with the First Fleet at Sydney Cove, the Gulf was already a well established site of cultural exchange and commerce. The appearance of the alien Asian was a spectre that haunted the pages of the colonial press (think of the Bulletin, the Lone Hand or Mary Gilmore's columns later in the Worker) and produced anxieties in the popular culture (Walker 1998). The presence of the colonised other was also registered at the heart of Empire, both in the flesh, as touring exhibits (Poignant, 1993) and discursively in the work of reformers like Joseph Salter and records of the London City Mission (Lindeborg 1994). A proliferating discourse, whose genres spanned the urban anthropology of reformers like Henry Mayhew and the social fiction of writers like Charles Dickens, mapped and regulated the nineteenth century city. Praed's narrative is very conscious of those enterprises, and knowing as well about the popular discourses of theosophy and utopianism.

The episode which takes the 'explorers' to the lost city of the Red People invokes popular interest in utopian romance, and participates in a wider feminist interest in the reorganisation of social life to accommodate new forms of independent femininity. Charlotte Perkins Gilman's Herland, written in 1915, took up with similar themes, and imagined a feminist community discovered by three male explorers. Gilman's earlier work, Women and Economics (1898), had attracted international attention. Gilman's work crossed the boundaries of fiction, poetry and sociology: her utopian writing cannot be quarantined within this field as 'romance'. Similarly, Praed's writing crosses genre boundaries, borrowing from the urban anthropology of the social reformers in its close observation of the Red People. Their forms of kinship and sexual commerce, in which women have a pre-eminent place, are documented and implicitly compared with the reforms in personal life which followed from the legal challenges to coverture in the English courts. But the 3000 volume library at Borroloola is a remnant of another lost history, a history of social reform in Queensland which Praed was also likely to be aware of. The passage of the Co-operative Communities Act by the liberal McIlwraith and Griffth government in 1893 was the outcome of sustained debate about associational life. Some thirteen communes were established in the 1890 s, including one at Chillagoe on Cape York Peninsula, before their land titles were extinguished in 1895. These 


\section{KAY FERRES}

communities were modelled on the ideas of William Lane and on the village settlements of New Zealand. Their streets were named Liberty, Union and Freedom; the facilities provided included libraries. A number of them were established in places familiar to Praed from her girlhood: Gayndah and Chinchilla (Metcalf 1995; 1998).

So what I want to do here is to step back from the metaphorical spaces of Lemuria into the material spaces of social relations and to re-embody characters in this romance of the 'unexplored bush' as inhabitants of what Mary Louise Pratt has called the 'contact zone' of sexualised and racialised colonial space. The narrative of Anne's escape with Kombo traces 'itineraries' which map ${ }^{2}$ these new (and dangerous) spaces. Anticipating her freedom, Anne returns to the safe space of the family 'run' to discover instead the ruins of the homestead. The pastoral run, as the High Court heard in evidence in the Wik case, is an artefact of colonialism: a lease whose title is unlike any in English law, and which does not confer unlimited rights of ownership. The contested right to access and use of pastoral land resuited in 'little wars' between Europeans and Aboriginal groups which are recorded in many of Praed's novels. Here, Anne Marley becomes dependent on Kombo for her survival and freedom. By the end of the novel, she is returned to 'civilisation' and installed in its hierarchies of class. 'Baroness' Marley and Kombo, in their different ways, are relics of colonialism.

\section{Homecomings and returns}

When Anne Marley stages her disappearance aboard ship, in order to escape the loathsome bondage of marriage to Elias Bedo, her intention is to return to her home, the station run by her uncle Duncan. She arrives at Kooloola to find that the homestead has been attacked by Aborigines. This scene, of the 'massacre' of a white family, is several times repeated in Praed's writing. In this instance, Anne's first reaction is to fear that Kombo, who has made the terrible discovery, will succumb to 'the savage beast' which the sight of the slaughter has unleashed. It is Anne's 'indomitable spirit' which is called upon here to quell the 'savage'. In this first confrontation of the 'civilised' and the 'savage', mapped onto the landscape in the ruins of the homestead, the power of the coloniser is vested in Anne's character and transmitted through her gaze. But her power is also associated with the personal affiliation that has existed between the two since childhood and depends on physical proximity. The dimensions of colonial power at work here are complicated by gender: once recovered, Kombo's 'keen wit' takes charge of their situation, and he resumes his role as the protector and tactician to guide Anne, as she evades the threats posed by Bedo and the Native Police, as well as potentially hostile Aboriginal clans. Anne's anxiety about Kombo does not entirely diminish; and it is not until they take refuge in a cave at some distance from the homestead that her trust is restored and she reflects on the meaning of these events, which is made intelligible in terms of colonial conquest: 


\section{TROUBLED HOMECOMINGS: ROSA PRAED AND LEMURIA}

Anne almost cried sometimes when she thought of the treachery which pioneering Whites had dealt to [Kombo's] race.... When she thought of the dispossessed tribe dying out down south, killed by the very vices they had learned from Englishmen, her heart burned with indignation. Setting aside superstition, Kombo loved her and was true to her because she had been kind to him, and had never scoffed at his traditions, nor had tried to force on him a religion which experience told him had, on the part of its professors, led to outrage upon the women of his race, and cruelty to its men (Praed 1902: 66-67).

This indignation is directed at whites 'down south'. The narrative exempts Anne (and her Uncle Duncan) from white 'treachery', but it also links her indignation to a wider social debate about the treatment of Aborigines. In the 1880s The Queenslander sponsored a powerful attack on the use of the Native Police. This was later separately published as The Way We Civilise, 'one of the most influential political tracts in Australian history' according to Henry Reynolds (Reynolds 1998: 108). The editor's protest resonates with Anne's feelings (though the different register of the journalist's public outspokenness and Anne's private reflection is important):

This, in plain language, is how we deal with the aborigines: On occupying new territory the aboriginal inhabitants are treated in exactly the same way as the wild beasts or birds the settlers may find there. Their lives and their property, the nets, canoes, and weapons which represent as much labour to thern as the stock and the buildings of the white settler, are held by the Europeans as being at their absolute disposal. Their goods are taken away, their children forcibly stolen, their women carried away, entirely at the caprice of the white men. The least show of resistance is answered by a rifle bullet; in fact, the first introduction between blacks and whites is often marked by the unprovoked murder of some of the former- in order to make a commencement of the work of 'civilising' them (cited in Reynolds 1998: 109-10).

Anne's homecoming, from the point of her discovery of the homestead, is not a return but the beginning of a different journey into a 'suddenly unknown home territory' (Lindeborg 1994: 386). Her flight from her marriage (which Praed elsewhere called 'this terrible insoluble problem of civilisation') becomes in part a flight from the civilisation whose wrongs destroy her safe haven; so she turns to the bush.

This turning away takes Anne and Kombo into a space at once unknown and familiar, a 'space of interplay' as described by de Certeau. As the narrative unfolds, Anne endures a series of captivities. These confinements offer Anne certain freedoms:

The girl's buoyant spirits rose in these surroundings, which had upon her an effect at once soothing and intensely exhilarating. Here, amid perils and deprivations, she was happier than she had ever been in 


\section{KAY FERRES}

England, where the endless bricks and mortar had seemed to her a wall reaching to the sky, in which her prisoned soul fluttered with maimed pinions, where her body languished, and her will became inert and morbid. Here, Nature reclaimed her child (Praed 1902: 92).

Here it is 'civilisation' and its values which are called into question. In the spaces of her confinement, social and ethno-cultural boundaries are uncertain or provisional. As Anne's journey proceeds, her replacement of her tattered clothing with a garment of vines and feathers completes her association with the idealised world of nature.

Sara Mills has analysed spatial relations in colonial contexts, arguing that the conventional understanding of gender as organised through the separation of public and private space, and the association of (middle class) femininity with confinement cannot account for the complexity of sexualised and racialised power relations in the colonies. She considers the interplay of these social relations on both the 'idealised level of distance and separation' and at the level of the 'contact zone' (Mills 1996: 125). Mills' analysis is centred on India, where 'distance and separation' and 'contact' are organised by the spatial practices of architecture and town planning, which she takes as her object. My discussion of Anne's journey is similarly organised around her embodiment on these two levels. She occupies 'idealised space' among the Aborigines as the goddess Cloud-Daughter and among the Red People as the priestess. Keorah's willingness to surrender this exalted position is a sign of the unfreedom of idealised space. Anne enters the 'contact zone' directly in her interactions with Kombo, and by association with Hansen and Bedo. Both distance and contact are negotiated in Fugitive Anne through the dynamics of her embodied interactions and her (disembodied) voice.

The voice here substitutes for the gaze: where spectatorial regimes have been shown to be implicated in imperial power, the voice can negotiate distance and contact. Anne's repertoire mediates social relationships, entices intimacy, seduces; but it also distances and protects her. In addition, Anne's use of her voice - in singing and in her fluent use of Aboriginal languages - can be seen in the light of an Aboriginal understanding of the ear as the seat of intelligence (Poignant 1993: 51).

Once reunited with Hansen, however, the allure of Anne's voice is turned to other ends. He, along with Bedo, has been following her trail and instantly recognises the singer of Orpheus' lament for the loss of Euridyce - 'Che farò senza Euridice?' - despite her concealment. Hansen, the naturalist, has been busily collecting and classifying specimens of fauna. His journey through the unexplored bush has been geared to the production of scientific knowledge as a way of making its spaces intelligible. His scientific training and disposition restores Anne to a world of 'civilised' order. But their reunion is swiftly followed by a second episode of captivity, in the lost valley of the Red People. 
TROUBLED HOMECOMINGS: ROSA PRAED AND LEMURIA

\section{Anne Marley's journey}

Anne's escape across the familiar but uncanny terrain of Cape York and the Gulf involves subterfuge, a co-conspirator in Kombo and a series of disguises and impersonations. I prefer to use the term impersonation here, rather than cultural transvestism because, following Judith Butler, I want to emphasise the performative as the ground of identification. Her impersonations demonstrate how provisional Anne's 'primary' identification as a young Anglo-Celtic Australian is. More importantly, they draw attention to the performative aspect of the ethnicity of whiteness.

In the first part of her journey, Anne's impersonations as a Lascar and as an Aboriginal boy cut across 'scientific' models of 'natural' racial difference. Her stained skin is contrived, but her comportment and her accomplished performance on horseback diminish gender and racial difference. Indeed, when she reprises her 'feminine' appearance in anticipation of reunion with the Duncans, we are made aware of its artifice. In company with Kombo, however, Anne's anxieties about the instability of racial and national identity are also very much on the surface, especially in her concern about the risk of Kombo's reversion to savagery and her distaste at his 'uncivilised' relish in the consumption of human flesh.

Anne's occupation of 'idealised' space, effected by her singing voice, stabilises these uncertainties. The power of her 'sublime' voice registers in every context she moves across, but in quite different ways. The Aboriginal people who first take her captive accord her the status of a goddess because of it; she cannily exploits the power which accrues to this status to gain some solitude and distance and to preserve her precarious racial 'superiority'. Anne's vulnerability does not simply register as sexual; she understands that sexual exchange is regulated in Aboriginal culture but she also understands that Kombo's loyalty to her does not take precedence over other affiliations. Anne's voice is her protection. Her repertoire had charmed the passengers on board ship; now, however incongruously it sits with her circumstances, it guarantees her safety.

Sara Mills describes the 'sublime', when it refers to a viewing position inscribed in representations of landscape, as ' a supremely imperialist viewing/knowing position', a position which assumes a 'unified seeing subject', transcending and hence controlling the landscape. Further, the achievement of the sublime involves 'a moment of confrontation between a solitary individual ego and a landscape where these problems of conflict and otherness are resolved', where the other is incorporated (Mills 1996: 132). However, drawing on the work of Gillian Rose, Patricia Yaeger and Mary Louise Pratt, Mills suggests that the attainment of the sovereignty implicit in this position, difficult even for the masculine viewer, involves even more complex negotiations for women in the colonial context. Further, she insists that the sublime must be understood as embedded in social relations, and not as an experience which leaves those relations behind. The experience of transcendence aggrandises the subject, confirming and reifying their power; but it is not outside power. The effect of transcendence must be accounted for in terms of a grid of social relations, including the aesthetic (the response to the boundlessness of unexplored space), the 


\section{KAY FERRES}

scientific and administrative (the regulation of that space as territory, in which roles are differentiated on gendered lines) and the imperial (an authority distributed in gender differentiated ways). The Aborigines' installation of Anne as the goddess Cloud-Daughter cedes to her the distancing power of the sublime, here preserving rather than incorporating the mystique of Otherness, and, not unsurprisingly, when she is called upon to intervene during a pitched battle, Cloud-Daughter sings 'God Save the Queen' (Praed 1902: 94).

Anne's encounter with the Aborigines, and the narrative's description of her experience follows the pattern of anthropological specification of cultural difference: the reader is presented with details of topography, language, customs and ritual. In each of her adventures, she has a faithful companion (though Kombo marries Unda, and Keorah clearly has designs on Hansen) while her voice gives her unexpected power and a potential autonomy. But among the Red People, her isolation as the priestess is not empowering, merely protective. Her spiritual authority underwrites the freedoms of the others, while confining her. Her position among the Red People mimics the position of middle class women in nineteenth century Britain, whose claims to moral authority were grounded in their separation from the public world of politics and commerce.

That moral authority underpinned the claims to suffrage and other campaigns for social reform, particularly Caroline Norton's efforts to gain custody of children for mothers, and the work to achieve marriage law reform. Praed's narrative maintains an interest in marital misconduct, from the early revelations of Bedo's violence to Eric Hansen's earnest discussion of how she might achieve legal separation from a husband whose only interest is in her property, and in the 'anthropological' description of marriage customs and sexual practices among the Aborigines and the Red People. This interest centres on the regulation of the sexual instinct, for the narrative works with a view of sexuality as a line of demarcation between the 'civilised' and the 'savage'. The distinctive feature of this society is that women initiate sexual encounters: when Keorah is freed from the celibacy required of the priestess, Hansen is the particular object of her desire.

The narrative is thus propelled by variously motivated desires for knowledge of otherness: by Praed's interest in the regulation of the sexual behaviour of populations, by Hansen's scientific desire, by Bedo's pursuit of wealth and personal advantage. Each desire leaves its track, its 'tour describer', and each invokes different disciplinary techniques of classification and regulation. The effect is to multiply knowledges of 'othemess': to remind us of the variegated discourses on race and sexual difference circulating in the nineteenth century, and of the way those discourses were deployed by different interests, from abolitionists and social reformers in Britain to colonial 'settlers' and administrators and the Native Police. 
TROUBLED HOMECOMINGS: ROSA PRAED AND LEMURIA

\section{The Other at the centre of the empire}

The cataclysmic destruction of the lost city, Bedo's death and her inheritance propel Anne, Eric and Kombo back to the centre of Empire. The Epilogue reports that the metropolitan press comments on Hansen's lectures on antiquities and his demonstration of links between ancient American and Australian civilisations and on the interest they held for 'the representatives of fashion, science and culture' who flocked to hear them. The presence of Kombo, 'the highly intelligent and humorous aboriginal' on the lecture platform 'behind his master' also draws press attention. Further, Anne's accession to an 'old title... Iong in abeyance' associates her with the other objects of Hansen's antiquarian researches.

John Docker claims that the representation of vanished civilisations and the remnants of inferior races in Lemurian legend provides the basis of a 'comforting imperial myth'. (Docker 1991: 176). I would argue that the Epilogue does not achieve such closure, but instead situates the adventure narrative which precedes it as one of the forms in which the debates about antiquity and human origins circulated in the public domain. 'To explore Australian space was to plumb global time' (Griffiths 1996: 9). The narrative follows Anne across geographical space and into an expansive 'past'; the Epilogue displaces her journey and her knowledge with Hansen's collection of time's 'relics', both natural and human. The Red People represent a remnant civilisation, and while Aboriginal people are deemed 'savage', there is a great deal of ambivalence about the colonial practices which have been legitimated by that designation. Anne herself is restored to the imperial order through her inheritance, but becomes a curiosity. Surely the questions raised by the conjunction of the romance narrative with contemporary debates about 'civilisation' are about how the distance between metropolitan centre and colonial periphery is measured and maintained, and how the disparity between geological time and historical time is explained.

Recognising the heterogeneity of Praed's narrative (its mix of genres includes Lemurian legend, travel narrative and captivity narrative) allows its continuities with what I want to call 'urban anthropology' to become apparent. Anne's enactment of the role of the flaneur is not an unfamiliar one to the author of this text. With Justin McCarthy and the expatriate artist Mortimer Menpes, Praed had published The Grey River, an illustrated guide to that part of London between Battersea Park and the East End, in 1889. The focus of this work was the notion of time and civilisation, and the way past civilisations and the present world might be connected. The observation of the Red People's management of gender arrangements and the regulation of sexuality in Fugitive Anne uses the same techniques and takes as its object the description and measurement of populations in much the same way as early anthropologists did. While social reformers like Henry Mayhew used terms like 'tribe' and 'race' to classify the fine gradations of difference among London's labouring classes and the poor, those terms were not always used metaphorically. The Irish and other colonised peoples were very visible at the centre of Empire from the early nineteenth century, and highly refined systems of classification 'fixed' their difference in terms of racial characteristics (Young 1995). 
Joseph Salter, of the London City Mission, mapped the 'plague spots of Oriental vice' in London: in Whitechapel, Westminster and Shadwell, and the notorious haunts of 'Tiger Bay', a terrain also crossed by the investigative gaze of social reformers like the abolitionist Thomas Clarkson and of course Henry Mayhew. The 'vice' which attracted this scrutiny included sexual promiscuity and other forms of moral incontinence: drunkenness, opium use and so on. Salter left a rich record of his activity, in his daily log book at the Mission and in published works: The Asiatic in England; Sketches of Sixteen Years' Work Among Orientals (1873) and The East in the West; or Work among the Asiatics and Africans in London (1895). His moral and spiritual surveillance of what he called 'Heathenism in the Inner Radius' is directed to identifying and containing the contagion of difference. Ruth Lindeborg, who has described Salter's enterprise, comments that '[f]or the Missionary, the spectre of apparent savagery in the literal space of Englishness ... demands a remapping to mask and shore up precarious national and cultural boundaries' (Lindeborg 1994: 283). This spectre was embodied in the person of the Lascar, a generic type which incorporated a range of racialised differences.

In addition, by the late nineteenth century, the exhibition of 'savages' was an established feature of English life. North Queensland in this period was the scene of the capture of Aborigines by entrepreneurs of these live exhibits. Roslyn Poignant has uncovered details of the display of 'Aboriginal savages' in various 'show spaces' in Europe, including the Royal Anthropological Institute, the Universal Exposition of 1891 in Paris and the Crystal Palace. As she puts it, 'the metropolitan appetite for the exotic was insatiable' (Poignant 1993: 39). It is into this spectatorial context - as an object of both public and scientific curiosity - that Aborigines like Kombo came. The popularity of these exhibitions drew an outraged response from Charles Dickens in Household Words. Writing in 1853, he poured scom on the idea of the 'noble savage', but was even more scathing of the evident fascination with such exhibits: 'the whimpering over him with maudlin admiration, and the affecting to regret him, and the drawing of any comparison of advantage between the blemishes of civilisation and the tenor of his swinish life' (Dickens 1853: 337).

Poignant's work, however partially, restores a particular group of Aborigines Billy, Jenny, Little Toby and their companions - as subjects of colonial history from their fate as objects of anthropological and public sensation at the metropolitan centre. Her narrative takes two directions: she deconstructs the archival remnants of the exhibition and she uncovers the historical traces of their capture and the Parliamentary and press furore which broke out in Sydney around the activities of the entrepreneur Robert A. Cunningham (Poignant 1993: 46). Praed's Epilogue does not overtly comment on the display of Kombo, though it does note a significant change in his status: the 'black boy' and the 'Lascar' had been 'mates'; now the press reports restore the imperial order, subordinating Kombo to his 'master', Hansen. The Epilogue's scant two pages and its sardonic description of the cult of celebrity which grows up around Hansen while Anne all but disappears hardly constitute a 'recuperation' of the order challenged by other aspects of the narrative, unless of course that narrative has been read as a 'romance', and its heterogeneity not accounted for. 
TROUBLED HOMECOMINGS: ROSA PRAED AND LEMURIA

Anxiety about Englishness and the precariousness of colonial power is a pronounced feature of captivity narrative. Robert Dixon discusses Fugitive Anne in the context of captivity narratives written by women. Drawing on Annette Kolodny's work, he claims that in their hands this narrative 'becomes a site where the transgression of race, gender and nationality may be fictionally explored' (Dixon 1995: 58). He sees this transgression in terms of Anne's defiance of patriarchal authority. But the authority wielded by Bedo, Hansen and the ship's captain is not equivalent, nor even working in the same direction (the captain provided a separate cabin when Anne appeals for respite, Hansen becomes her partner). Nevertheless, it is evident that Australian and North American captivity narratives do have some commonalities, and a shared investment in nation formation.

The comparison I would like to draw is with Nancy Armstrong and Leonard Tennenhouse's discussion of Mary Rowlandson's Captivity Narrative, first published in 1682 and many times reprinted up to 1720 . Their argument is that this narrative, in its reiterated expressions of longing for the home from which Rowlandson is separated, serves not only to close that gap and to maintain her identity as English, but also distinguishes the New World community from the Old World it left behind (Armstrong and Tennenhouse 1992: 211). The captivity narrative is a means of 'individuating English consciousness and of placing it in a position of mastery over all it surveys' (Armstrong and Tennenhouse 1992: 213), but this involves differentiating metropolitan from colonial forms of Englishness.

Reading Praed's narrative in terms of the way it contrasts metropolitan and colonial forms of Englishness brings spatially separate colonial encounters into close proximity, and locates Anne (and Praed) in both places at once. Anne's journeys between the metropolitan centre and the colony, coming home to Australia, and returning to England with Hansen as Baroness Marley, set her on different trajectories through cultural and national difference. Those trajectories, and her various embodiments in them, become entangled in multi-layered relations of power and raise questions about the legitimacy of patriarchal and colonial authority. Anne finds herself not in the spaces of 'freedorn' but in 'abstract space', the space of vanquishment. In Praed's heterogeneous narrative, the spaces mapped by Anne's itinerary are at once uncanny and familiar, not yet 'collated on the same plane'. The social reformers mapped spaces of confinement and enclosure of the other on the dark continent of the city of London. Anne Marley goes into the unexplored bush as a contact zone, where gendered and racial identities are reconfigured and the social and colonial relations with which they are implicated are unsettled. The Epilogue re-establishes the imperial order of things, as Hansen assumes centre stage, but at the cost of Anne and Kombo's freedom to be friends. The New World's forms of civility stand in contrast to the manners and class stratification of the Old. 


\section{KAY FERRES}

\section{Works cited}

Armstrong, Nancy and Leonard Tennenhouse 1992, The Imaginary Puritan: Literature, Intellectual Labor and the Origins of Personal Life, University of California Press, Berkeley.

Butler, Judith 1995, Bodies That Matter. On the Discursive Limits of 'Sex', Routledge, New York. de Certeau, Michel 1984, The Practice of Everyday Life, University of California Press, Berkeley. Dickens, Charles 1853, 'The Noble Savage', Household Words 7, 337-39.

Dixon, Robert 1993, 'The New Woman and the Coming Man: Gender and Genre in the Lost-Race Romance' in Debutante Nation: Feminism Contests the 1890, eds Susan Magarey, Sue Rowley and Susan Sheridan, Allen and Unwin, Sydney.

Dixon, Robert 1995, Writing the Colonial Adventure: Race, Gender and Nation in Anglo-Australian Popular Fiction, 1875-1914, Cambridge University Press, Melbourne.

Docker, John 1991, The Nervous Nineties: Australian Cultural Life in the 1890s, Oxford University Press, Melbourne.

Griffiths, Tom 1996, Hunters and Collectors: The Antiquarian Imagination in Australia, Cambridge University Press, Melboume.

Jacobs, Jane M. 1996, Edge of Empire: Postcolonialism and the City, Routledge, London.

Lindeborg, Ruth H. 1994, 'The "Asiatic" and the Boundaries of Victorian Englishness', Victorian Studies, Spring, 381-404.

Metcalf, Bill, (ed.) 1995. From Utopian Dreaming to Communal Reality: Cooperative Lifestyles in Australia, University of New South Wales Press, Sydney.

Metcalf, Bill 1998, The Gayndah Communes, Central Queensland University Press, Rockhampton. Mills, Sara 1996, 'Gender and Colonial Space', Gender, Place and Culture, 3.2, 124-42.

Poignant, Rosiyn 1993, 'Captive Aboriginal lives: Billy, Jenny, Little Toby and Their Companions' in Captive Lives: Australian Captivity Narratives, ed. Kate Darian-Smith, Sir Robert Menzies Centre for Australian Studies, London.

Praed, Rosa Caroline 1902, Fugitive Anne: A Romance of the Unexplored Bush, John Long, London.

Praed, Rosa Caroline, Justin McCarthy and Mortimer Menpes 1889, The Grey River. Seeley, London.

Reynolds, Henry 1998, This Whispering in Our Hearts, Sydney: Allen and Unwin.

Sharkey, Michael 1983, 'Rosa Praed's Colonial Heroines' in Who is She? Images of Woman in Australian Fiction, ed. Shirley Walker, University of Queensland Press, St Lucia.

Rose, Nikolas 1999, Powers of Freedom: Reframing Political Thought, Cambridge University Press, Cambridge.

Schul, Dennis 1991, 'City of Dreams' in The Australian Magazine, August 3-4.

Walker, David 1998, Anxious Nation: Australia and the Rise of Asia 1850-1939, University of Queensland Press, St Lucia.

Young, Robert J.C. 1995, Colonial Desire: Hybridity in Theory, Culture and Race, Routledge, London.

\section{Notes}

1 An earlier version of this paper was delivered at ASAL 1997, University of New England.

2 I mean 'map' to include both the material and the metaphorical here: to retain the traces of the 'tour describers' (the itineraries of actual joumeys) and to refer to the more familiar representation which 'collates on the same plane heterogeneous places, some received from a tradition and others produced by observation' as de Certeau describes (1984: 120-21). 